\title{
STRIPAK, a Key Regulator of Fungal Development, Operates as a Multifunctional Signaling Hub
}

\author{
Ulrich Kück*(D) and Valentina Stein \\ Allgemeine und Molekulare Botanik, Faculty for Biology and Biotechnology, Ruhr-University, \\ 44780 Bochum, Germany; valentina.stein@rub.de \\ * Correspondence: ulrich.kueck@rub.de
}

Citation: Kück, U.; Stein, V. STRIPAK, a Key Regulator of Fungal Development, Operates as a Multifunctional Signaling Hub. J. Fungi 2021, 7, 443. https://doi.org/ $10.3390 /$ jof7060443

Academic Editor: Robert A. Arkowitz

Received: 26 April 2021

Accepted: 29 May 2021

Published: 1 June 2021

Publisher's Note: MDPI stays neutral with regard to jurisdictional claims in published maps and institutional affiliations.

Copyright: (c) 2021 by the authors. Licensee MDPI, Basel, Switzerland. This article is an open access article distributed under the terms and conditions of the Creative Commons Attribution (CC BY) license (https:/ / creativecommons.org/licenses/by/ $4.0 /)$.

\begin{abstract}
The striatin-interacting phosphatases and kinases (STRIPAK) multi subunit complex is a highly conserved signaling complex that controls diverse developmental processes in higher and lower eukaryotes. In this perspective article, we summarize how STRIPAK controls diverse developmental processes in euascomycetes, such as fruiting body formation, cell fusion, sexual and vegetative development, pathogenicity, symbiosis, as well as secondary metabolism. Recent structural investigations revealed information about the assembly and stoichiometry of the complex enabling it to act as a signaling hub. Multiple organellar targeting of STRIPAK subunits suggests how this complex connects several signaling transduction pathways involved in diverse cellular developmental processes. Furthermore, recent phosphoproteomic analysis shows that STRIPAK controls the dephosphorylation of subunits from several signaling complexes. We also refer to recent findings in yeast, where the STRIPAK homologue connects conserved signaling pathways, and based on this we suggest how so far non-characterized proteins may functions as receptors connecting mitophagy with the STRIPAK signaling complex. Such lines of investigation should contribute to the overall mechanistic understanding of how STRIPAK controls development in euascomycetes and beyond.
\end{abstract}

Keywords: STRIPAK complex; mitophagy; multifunctional signaling hub; fungal development; Sordaria macrospora

\section{Introduction}

Posttranslational phosphorylation of eukaryotic proteins plays an essential role in modulating their function and is tightly regulated in time and space by the fine-tuned balance between protein kinases and phosphatases [1]. The serine/threonine protein phosphatase PP2A is a heterotrimeric holoenzyme comprising a structural (PP2AA), a catalytic (PP2Ac), and a regulatory B subunit. So far, four different regulatory subunits are known, $\mathrm{B}, \mathrm{B}^{\prime}, \mathrm{B}^{\prime \prime}$, and $\mathrm{B}^{\prime \prime \prime}$. Subunit $\mathrm{B}^{\prime \prime \prime}$ is designated as striatin and is the name-giving subunit of the striatin-interacting phosphatases and kinases (STRIPAK) signaling complex. This multimeric complex, first characterized in mammalian cells [2], and found to be involved in the regulation of various target proteins, contains a number of other core components. Mass spectrometry analysis primarily characterized different subunits of STRIPAK in mammalian or fungal systems, and various reviews summarize the basic components of the complex [3-6]. In addition to the PP2A holoenzyme, these are the striatin-interacting proteins STRIP1/2, the mammalian Mps one binder homolog Mob3/phocein, the sarcolemmal membrane-associated protein (SLMAP), and the coiled-coil protein suppressor of IкB kinase- $\varepsilon$ (SIKE). These subunits have been characterized in various eukaryotic STRIPAK complexes (for review see $[4,5]$ ), and the synonymous designations in euascomycetes are found in Table 1.

Here, we briefly summarize our current knowledge about the function of the STRIPAK complex of ascomycetes, with an emphasis on the role of euascomycetous development. 
We further refer to recent structural investigations and cellular analyses, which help us understand how STRIPAK acts as a scaffolding complex that cross-links several signal transduction pathways. Finally, current molecular cellular investigations of the STRIPAK homologue in yeast provide insights into a mechanistical hypothesis of how STRIPAK interacts with other signaling pathways at the cellular level, and thus integrates various developmental programs.

\section{The Structure of STRIPAK Suggests the Integration of Diverse Cellular Signals}

Striatin is the central subunit of STRIPAK, and the primary structure of this $\mathrm{B}^{\prime \prime \prime}$ subunit is conserved in all eukaryotic systems studied so far [3-6]. Striatins have four domains: an N-terminal caveolin-binding domain, a coiled-coil domain, a calmodulin-binding domain, and a C-terminal WD40 repeat domain. Important for the cellular localization and complex assembly is the coiled-coil domain, which further mediates its homo- or heterooligomerization. Crystal structures of the coiled-coil domain indicated a parallel dimeric but asymmetric conformation of striatin containing a large bend [7].

Although the association of STRIPAK into a heterotrimeric holoenzyme is validated, the overall structure of the complex and knowledge about the stoichiometric composition of the subunits are still cryptic. Assembly of the fungal STRIPAK complex was recently investigated in the euascomycete Aspergillus nidulans [8]. Using wild type and STRIPAK subunit deletion strains, these studies showed that the STRIPAK complex is formed from three subcomplexes (SIKE-SLMAP, MOB3, and STRIP1/2-PP2Ac1-PP2AA), where striatin acts as a scaffold at the nuclear envelope. Previous crystallographic analysis had explored the subunit stoichiometry from mammalian STRIPAK, thus promoting our understanding of the different biological functions $[9,10]$. A further refinement of the structure of a purified human protein complex was very recently determined by cryo-EM, at 3.2-Å resolution [11]. STRIPAK contains four copies of striatin and one copy of each of the other subunits. According to this study, the four WD40 repeat domains from the four striatins interact with different activators or suppressors of other signaling pathways. Included is the Hippo signaling pathway, which is conserved within eukaryotes [12]. The high conservation of STRIPAK subunits allows us to speculate that the structural implications derived from analysis of the mammalian complex can be transferred to STRIPAK of fungal organisms.

\section{STRIPAK Subunits Have an Impact on Fungal Development}

Distinct genes encoding subunits of the STRIPAK complex have been analyzed in a variety of filamentous ascomycetes. Mutations in the corresponding genes lead to severe developmental defects as summarized in Table 1. Here, we summarize how defects in subunits of the STRIPAK complex affect fungal development. Initially, genes for STRIPAK subunits were detected upon investigating the formation of fruiting bodies or hyphal cell fusion (for review see [4]). In Sordaria macrospora, a self-fertile homothallic member of the Sordariaceae family, sterile strains were screened for mutant genes, many of which were found to encode STRIPAK subunits. The mutants only generated small immature fruiting bodies, called protoperithecia of about $50 \mu \mathrm{m}$ in diameter, and contained no ascospores nor asci. Fertility was clearly restored when the wild type subunit gene was introduced into the mutant genome [13]. Such STRIPAK control of fruiting body formation has been observed in a variety of ascomycetes, as summarized in Table 1.

In an analogous mutant screen, Neurospora crassa strains with a defect in cell-cell fusion were investigated and the genes responsible were abbreviated as HAM for hyphal anastomosis. Of these, several showed a mutation in genes for STRIPAK subunits, such as HAM-2, -3 , and -4 [14-16]. Cell-cell fusions are not only the starting process for sexual development and fruiting body formation but seems also to be important in some symbiotic interactions with other organisms, as well as in infection processes by pathogenic species. A common feature of many STRIPAK mutants is a block in the sexual life cycle. However, in heterothallic species, such as $N$. crassa, female but not male fertility is affected by mutant genes for STRIPAK subunits. Furthermore, it has been hypothesized that the lack of hyphal 
fusions leads to impaired nuclear division during meiosis and to the formation of abnormal ascospores. These observations led to the hypothesis that subunits of STRIPAK are involved in regulating the cell cycle [17]. In this context, it is relevant that not only septation of vegetative hyphae but also of female gametangia (ascocogonia) is apparently controlled by subunits of STRIPAK [18-20].

A remarkable effect was observed in $A$. nidulans when proper expression of the velvet complex [21] was investigated in mutants lacking STRIPAK subunits. The mutants showed not only an absence of light-dependent fungal development and secondary metabolite production, but also a reduced stress response [8].

Plant-fungal interactions are another developmental process that is controlled by STRIPAK. Epichloë festucae forms a mutualistic symbiotic relationship with the grass Lolium perenne. The fungus produces several secondary metabolites thus protecting the host against herbivores. This interaction arises by fungal colonization of intercellular spaces and the leaf surface. Loss of $m o b C$, which is homologous to mob3, completely abolishes the symbiotic interaction between the fungus and the grass. Instead, E. festucae shows extensive hyphal growth within the intercellular tissue of the grass, and in addition, hyphae are found within the vascular bundle tissue, which was never observed with the wild type. Infection with the mobC mutant leads to underdeveloped grasses, lacking a functional association with the fungal symbiont [22].

For a long time, plant pathogenic fungi were the subjects of genetic analysis in order to understand their pathogenic mechanisms. These investigations revealed that STRIPAK controls the virulence process in plant pathogens such as Colletotrichum graminicola, Fusarium verticillioides, Fusarium virguliforme, and Magnaporthe oryzae. In the corn pathogen F. verticillioides, the N-terminal domains of the striatin homologue Fsr1, as well as the STRIP1/2 homologue FvStp1 are important in maize stalk rot virulence [23-25]. Similarly, in another corn pathogen, C. graminicola, striatin null mutants have functional appressoria; however, the colonization leading to infection is diminished [26]. Virulence was similarly investigated in the soybean pathogen F. virguliforme. Here, the striatin homologue FvStr1 controls the colonization of the vascular system, although phloem and xylem vessels of the roots are still infected by mutants [27]. In the rice blast fungus $M$. oryzae, strains lacking the catalytic subunit of PP2A (MoPPG1) were unable to form appressoria for penetrating the host plant [28]. From these examples, it becomes evident that STRIPAK controls in some instances plant-fungal relationships by controlling cell-cell interactions and the formation of infection structures.

So far however, reports are lacking that fungal-animal interactions are controlled by STRIPAK. For example, nematode trapping fungi were recently investigated genetically and shown to be dependent on conserved signaling networks for developing specialized trap structures to capture, kill, and consume nematodes [29-31]. We predict that loss of STRIPAK components will result in defects of animal trapping. Similarly, the virulence of approximately 625 fungal species that infect vertebrates [32] were not reported to be controlled by STRIPAK. It may be envisioned that future molecular genetic studies in well-studied human pathogens such as Aspergillus fumigatus, Candida albicans, Cryptococcus neoformans, or Histoplasma capsulatum will discover virulence mutants with a defect in genes for subunits of the STRIPAK complex. This assumption is supported by the fact that genes for STRIPAK subunits are very similar between pathogenic and non-pathogenic ascomycetes and basidiomycetes. At least, so far characterized protein domains in homologues of striatin, SLMAP and STRIP1/2 seem to be highly conserved (Figures S1-S3). An exception seems to be the yeast $C$. albicans. This pathogen has a truncated gene for a striatin-like protein, lacking WD40 repeats. With this, it resembles the FAR11 protein from baker's yeast, which is referred to in the final section [33]. 


\section{Dual Localization of STRIPAK Connects Signaling Pathways}

The previous section reviewed the diverse developmental processes controlled by STRIPAK. Thus, the question arises as to how this protein complex regulates mechanistically diverse processes within a single organism.

Eukaryotic cells are compartmentalized within membrane-bound organelles, and multiple targeting of proteins or protein complexes can arise through distinct mechanisms during evolution or by stepwise accumulation of mutations within new subunits of a macromolecular complex [34,35]. In various euascomycetes, localization studies have detected STRIPAK subunits at different membranes within the fungal cell, such as the nuclear membrane, the endoplasmatic reticulum (ER), or the mitochondrial outer membranes $[8,15,25,36]$, (Table 2). For A. nidulans and F. verticillium, more than one cellular localization was reported, and removing striatin by mutation resulted in dislocalization of the remaining STRIPAK subunits $[8,25]$. Structured illumination microscopy (SIM) in $S$. macrospora showed in detail that PRO45, the homologue of SLMAP, resides in the nuclear envelope, the mitochondrial membrane and the spindle pole body. These results led to the hypothesis that this SLMAP homologue functions as a membrane organizer to mediate signaling by bridging two or more organelles [36]. These findings are compatible to studies with mammalian cells where the SLMAP subunit of STRIPAK resides in the sarcolemma, transverse (T)-tubules, and sarcoplasmic reticulum (SR) of muscle cells, as well as in the outer nuclear envelope, ER, mitochondria, and centrosomes of non-muscle cells [37-41]. Such close associations, for example, between mitochondria and the ER, is believed to transmit calcium signals necessary for balanced cell metabolism [42].

Genetic and molecular analysis in fungi has shown previously that STRIPAK is associated with signaling transduction pathways. In N. crassa, for example, subunits of STRIPAK components are involved in the nuclear localization of MAK-1, the downstream kinase of the cell wall integrity (CWI) pathway [15], which supports the hypothesis of crosstalk between the STRIPAK complex and other signaling transduction pathways in fungi. This seems to be consistent with a recent phosphoproteomic analysis, demonstrating that subunits of diverse signaling complexes, such as the target of rapamycin complex 2 (TORC2), nicotinamide adenine dinucleotide phosphate oxidase (NOX), septation initiation network (SIN), CWI and pheromone response (PR) pathway, were phosphorylated or dephosphorylated in a STRIPAK-dependent manner [43,44].

A recent report from the protoascomycete Saccharomyces cerevisiae broadens our mechanistic view of how multiple cellular localizations of STRIPAK subunits connect to signaling transduction pathways [45]. In yeast, the factor arrest (FAR) complex is the STRIPAK homologue, which, for example, controls vacuolar protein sorting and pheromone-induced cell cycle arrest. Subpopulations of FAR reside either in the ER or in the mitochondria, and this localization is determined by the tail-anchor domain of Far9/10, the homologue of SLMAP. When located in the ER, FAR regulates the TORC2 signaling pathway, while its location in the mitochondrial membrane inhibits mitophagy, a process were mitochondria are selectively degraded by autophagy. The yeast mitophagy receptor Atg32p was shown to interact with Far8p, the homologue of striatin. Atg32p is phosphorylated by casein kinase 2 (CK2), which is essential for mitophagy. The phosphorylation is counteracted by the FAR complex, causing to dissociate from Atg32p upon mitophagy stimuli [46].

So far, a homologue of Atg32p has neither been detected in mammals nor in filamentous euascomycetes $[47,48]$. However, for mammalian cells, eight mitophagy receptors were described, of which one, Bcl2-L-13, is functionally homologous to Atg32p [49,50]. Like Atg32p, Bcl2-L-13 carries a C-terminal transmembrane domain (TM), an amino acid acidic cluster, and an LC3-interacting region (LIR), which binds ATG8 and corresponds to the Atg8-interacting motifs (AIM) in yeast [51]. Finally, Atg32p and Bcl2-L-13 are characterized by a CK2 phosphorylation site and a PP2A docking site. Atg32p additionally carries an Atg11 binding region (A11BR), which is predicted to bind Atg11p.

In diverse genomes of euascomycetes, no homologue of the Atg32p or Bcl2-L-13 gene has been detected [48]. Therefore, we searched for S. macrospora genes encoding proteins 
with sequence motifs that are characteristically found in Atg32p and/or Bcl2-L-13. Indeed, we detected 27 genes (Table S1) in the complete and well-curated S. macrospora genome encoding proteins with these domains or motifs [52,53]. Among these, six genes were found exclusively in euascomycetes (Table S1). Interestingly, one of the candidate proteins (SMAC_04227) is present in the recently characterized library of STRIPAK-dependent phosphorylated proteins from S. macrospora $[43,44]$. Thus, we hypothesize that the so far uncharacterized S. macrospora protein SMAC_04227 is potentially functioning as a mitophagy receptor, which similar to Atg32p from yeast, connects the STRIPAK complex to mitophagy. Within euascomycetes, SMAC_04227 shows a high sequence similarity to other homologues (Figure S2), and in future functional investigations it will be worth testing whether the phosphorylation status of SMAC_04227 affects an interaction with STRIPAK subunits. Functionally similar to yeast, the phosphorylation of SMAC_04227 or its homologues may promote mitophagy, a process which is being intensively investigated in euascomycetes [47,48,54-57].

We predict that future investigations will address the question, how STRIPAK controls pathogenic and symbiotic interaction of fungi with plants, animals, including humans, and other microorganisms. Finally, we do not know what regulates the different cellular locations of STRIPAK. This question is associated with the problem of how phosphorylation and dephosphorylation controls the interaction or dissociation of STRIPAK with other signaling complexes. We anticipate that research in this direction will benefit from advances in mass spectrometry-based methods for more comprehensive site-specific phosphorylation profiling. This was recently demonstrated when absolute quantification by parallel-reaction monitoring (PRM) was applied to analyze phosphorylation site occupancy in signaling components of the SIN signaling pathway [58]. In conclusion, well established experimental systems in diverse euascomycetes should contribute to answering these questions and will contribute to the overall mechanistic understanding of how STRIPAK regulates not just euascomycetes development, but in eukaryotes in general. 
Table 1. List of genes encoding STRIPAK subunits and STRIPAK associated kinases, which are all involved in different developmental processes in euascomycetes.

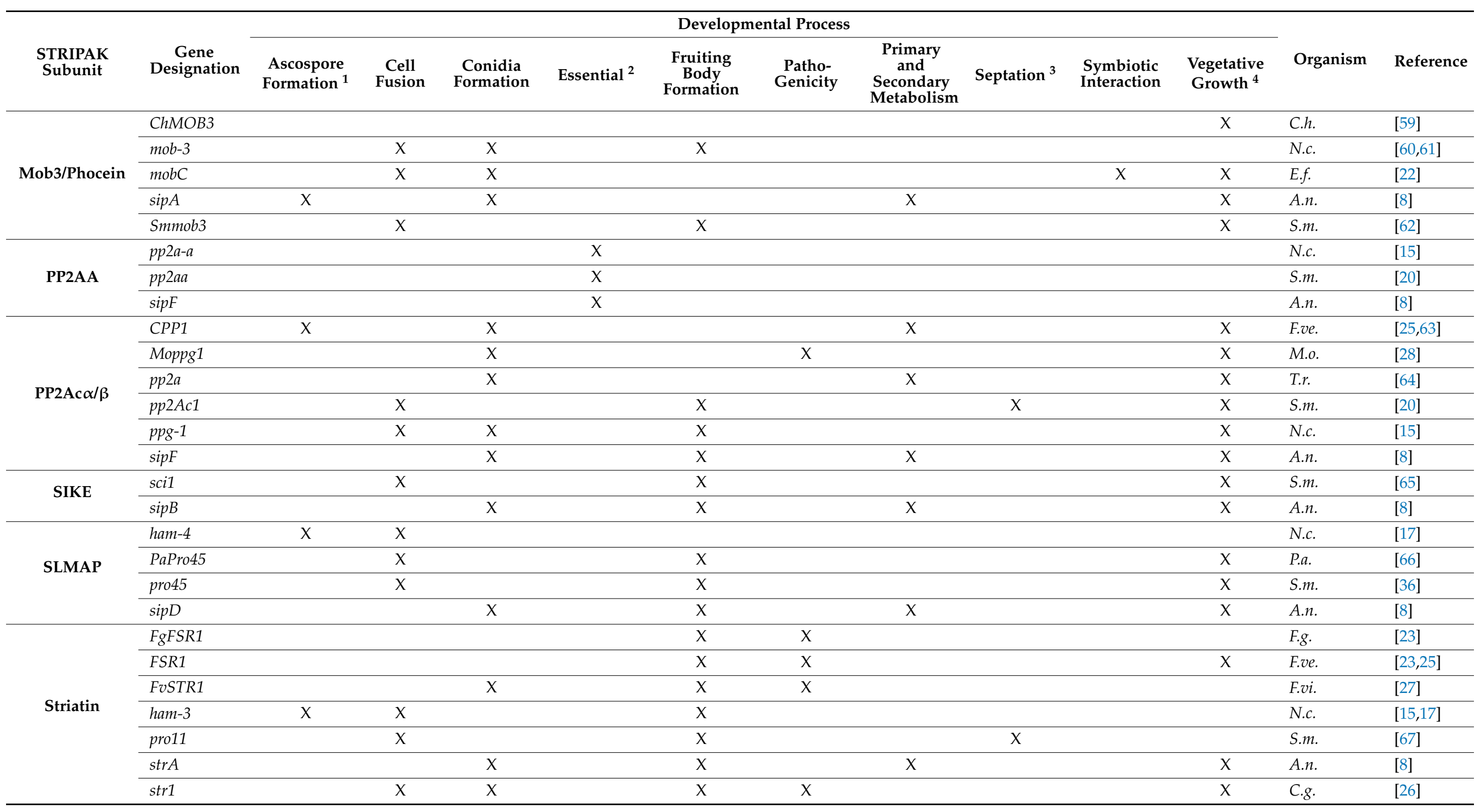


Table 1. Cont.

\begin{tabular}{|c|c|c|c|c|c|c|c|c|c|c|c|c|c|}
\hline \multirow[b]{2}{*}{$\begin{array}{c}\text { STRIPAK } \\
\text { Subunit }\end{array}$} & \multirow[b]{2}{*}{$\begin{array}{c}\text { Gene } \\
\text { Designation }\end{array}$} & \multicolumn{10}{|c|}{ Developmental Process } & \multirow[b]{2}{*}{ Organism } & \multirow[b]{2}{*}{ Reference } \\
\hline & & $\begin{array}{c}\text { Ascospore } \\
\text { Formation } \\
1\end{array}$ & $\begin{array}{c}\text { Cell } \\
\text { Fusion }\end{array}$ & $\begin{array}{l}\text { Conidia } \\
\text { Formation }\end{array}$ & Essential $^{2}$ & $\begin{array}{l}\text { Fruiting } \\
\text { Body } \\
\text { Formation }\end{array}$ & $\begin{array}{l}\text { Patho- } \\
\text { Genicity }\end{array}$ & $\begin{array}{l}\text { Primary } \\
\quad \text { and } \\
\text { Secondary } \\
\text { Metabolism }\end{array}$ & $\underset{3}{\text { Septation }}$ & $\begin{array}{l}\text { Symbiotic } \\
\text { Interaction }\end{array}$ & $\begin{array}{l}\text { Vegetative } \\
\text { Growth }\end{array}$ & & \\
\hline \multirow{5}{*}{ STRIP1/2 } & ham-2 & $X$ & $X$ & & & $X$ & & & & & & N.c. & [17] \\
\hline & PaPro22 & & $x$ & & & $x$ & & & & & $x$ & P.a. & [66] \\
\hline & pro22 & & $x$ & & & $x$ & & & $x$ & & & S.m. & {$[18]$} \\
\hline & $\operatorname{sip} C$ & & & $x$ & & $x$ & & $x$ & & & $x$ & A.n. & [8] \\
\hline & FvSTP1 & & & & & $x$ & $x$ & & & & $x$ & F.ve. & [25] \\
\hline \multicolumn{14}{|c|}{ STRIPAK associated kinases } \\
\hline \multirow{4}{*}{ GCKIII } & Fg07344 & $X$ & & $X$ & & & $X$ & & & & $X$ & F.g. & [68] \\
\hline & sepL & & & $x$ & & & & & $x$ & & $x$ & A.n. & [69] \\
\hline & sid-1, mst-1 & & & & & $X$ & & & $x$ & & & N.c. & {$[70]$} \\
\hline & $\begin{array}{l}\text { Smkin3, } \\
\text { Smkin24 }\end{array}$ & & $x$ & & & $x$ & & & $x$ & & $x$ & S.m. & {$[19,71]$} \\
\hline
\end{tabular}

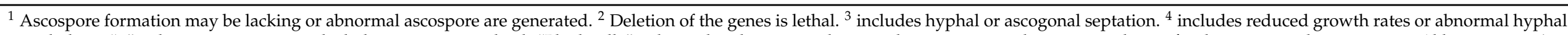

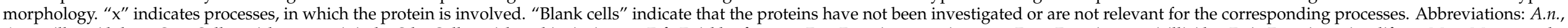

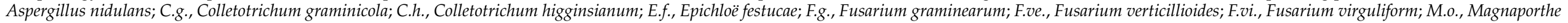
oryzae; N.c., Neurospora crassa; P.a., Podospora anserina; S.m., Sordaria macrospora; T.r., Trichoderma reeset. 
Table 2. Localization of STRIPAK subunits in various euascomycetes.

\begin{tabular}{|c|c|c|c|c|}
\hline Subunit & & Organism & Localization & Reference \\
\hline \multirow{3}{*}{ Mob3/Phocein } & MOB-3 & N. crassa & Nuclear envelope & [15] \\
\hline & SmMOB3 & S. macrospora & Nuclear envelope & [72] \\
\hline & SipA & A. nidulans & $\begin{array}{l}\text { ER (string-like extensions), nuclear envelope (dependant } \\
\text { on StrA), nucelus }\end{array}$ & {$[8]$} \\
\hline \multirow{2}{*}{$\mathrm{PP} 2 \mathrm{Ac} \alpha / \beta$} & PPG-1 & N. crassa & Nucleus & [15] \\
\hline & SipE & A. nidulans & Nuclear envelope (dependant on StrA) & [8] \\
\hline \multirow{2}{*}{ SIKE } & SCI1 & S. macrospora & Nuclear envelope & [65] \\
\hline & SipB & A. nidulans & Nuclear envelope (dependant on StrA) & [8] \\
\hline \multirow{3}{*}{ SLMAP } & HAM-4 & N. crassa & Nuclear envelope & [15] \\
\hline & PRO45 & S. macrospora & $\begin{array}{l}\text { Nuclear envelope, the mitochondrial membrane and the } \\
\text { spindle pole body }\end{array}$ & {$[36]$} \\
\hline & SipD & A. nidulans & Nuclear envelope (dependant on StrA) & [8] \\
\hline \multirow{4}{*}{ Striatin } & Fsr1 & F. verticillioides & $\begin{array}{l}\text { ER, nuclear envelope, vacuolar membranes or late } \\
\text { endosomes in }\end{array}$ & [25] \\
\hline & HAM-3 & N. crassa & Nuclear envelope & [15] \\
\hline & PRO11 & S. macrospora & Nuclear envelope & [65] \\
\hline & StrA & A. nidulans & ER, nuclear envelope, & {$[8,73]$} \\
\hline \multirow{3}{*}{ STRIP1/2 } & HAM-2 & N. crassa & Nuclear envelope & [15] \\
\hline & PRO22 & S. macrospora & dynamic tubular and vesicular vacuolar network & {$[18]$} \\
\hline & SipC & A. nidulans & Nuclear envelope (dependant on StrA) & {$[8]$} \\
\hline \multirow{2}{*}{ GCKIII } & SID-1 & N. crassa & Spindle pole body (SPB), septa & {$[70]$} \\
\hline & SmKIN3 & S. macrospora & Spindle pole body (SPB), septa & {$[58]$} \\
\hline
\end{tabular}

Supplementary Materials: The following are available online at https: / www.mdpi.com/article/ 10.3390/jof7060443/s1, Figure S1: Alignment of striatin homologues in selected fungi. Figure S2: Alignment of SLMAP homologues in selected fungi. Figure S3: Alignment of STRIP1/2 homologues in selected fungi. Figure S4: Domain organization of SMAC_04227 in S. macrospora, Bcl-2-L-13 in H. sapiens and Atg32p in S. cerevisiae. Table S1: Identification of 27 putative Atg32p homologoues using eight different criteria.

Author Contributions: Conceptualization, U.K. and V.S.; investigation, V.S.; data curation, V.S.; writing—original draft preparation, U.K.; writing—review and editing, U.K. and V.S.; visualization V.S.; supervision, U.K.; project administration, U.K.; funding acquisition, U.K. All authors have read and agreed to the published version of the manuscript.

Funding: This research was funded by Deutsche Forschungsgesellschaft (DFG), Germany, grant number KU517/16-1, KU517/16-2.

Institutional Review Board Statement: Not applicable.

Informed Consent Statement: Not applicable.

Data Availability Statement: Not applicable.

Acknowledgments: We acknowledge support by the Open Access Publication Funds of the RuhrUniversität Bochum.

Conflicts of Interest: The authors declare no conflict of interest. 


\section{References}

1. Den Hertog, J. Regulation of protein phosphatases in disease and behaviour. EMBO Rep. 2003, 4, 1027-1032. [CrossRef]

2. Goudreault, M.; D’Ambrosio, L.M.; Kean, M.J.; Mullin, M.J.; Larsen, B.G.; Sanchez, A.; Chaudhry, S.; Chen, G.I.; Sicheri, F.; Nesvizhskii, A.I.; et al. A PP2A phosphatase high density interaction network identifies a novel striatin-interacting phosphatase and kinase complex linked to the cerebral cavernous malformation 3 (CCM3) protein. Mol. Cell. Proteom. 2009, 8, 157-171. [CrossRef]

3. Hwang, J.; Pallas, D.C. STRIPAK complexes: Structure, biological function, and involvement in human diseases. Int. J. Biochem. Cell Biol. 2014, 47, 118-148. [CrossRef]

4. Kück, U.; Beier, A.M.; Teichert, I. The composition and function of the striatin-interacting phosphatases and kinases (STRIPAK) complex in fungi. Fungal Genet. Biol. 2016, 90, 31-38. [CrossRef]

5. Kück, U.; Radchenko, D.; Teichert, I. STRIPAK, a highly conserved signaling complex, controls multiple eukaryotic cellular and developmental processes and is linked with human diseases. Biol. Chem. 2019, 400, 1005-1022. [CrossRef]

6. Shi, Z.; Jiao, S.; Zhou, Z. STRIPAK complexes in cell signaling and cancer. Oncogene 2016, 35, 4549-4557. [CrossRef] [PubMed]

7. Chen, C.; Shi, Z.; Zhang, W.; Chen, M.; He, F.; Zhang, Z.; Wang, Y.; Feng, M.; Wang, W.; Zhao, Y.; et al. Striatins contain a noncanonical coiled coil that binds protein phosphatase 2AA subunit to form a 2:2 heterotetrameric core of striatin-interacting phosphatase and kinase (STRIPAK) complex. J. Biol. Chem. 2014, 289, 9651-9661. [CrossRef] [PubMed]

8. Elramli, N.; Karahoda, B.; Sarikaya-Bayram, O.; Frawley, D.; Ulas, M.; Oakley, C.E.; Oakley, B.R.; Seiler, S.; Bayram, O. Assembly of a heptameric STRIPAK complex is required for coordination of light-dependent multicellular fungal development with secondary metabolism in Aspergillus nidulans. PLoS Genet. 2019, 15, e1008053. [CrossRef]

9. Tang, Y.; Chen, M.; Zhou, L.; Ma, J.; Li, Y.; Zhang, H.; Shi, Z.; Xu, Q.; Zhang, X.; Gao, Z.; et al. Architecture, substructures, and dynamic assembly of STRIPAK complexes in Hippo signaling. Cell Discov. 2019, 5, 3. [CrossRef] [PubMed]

10. Chen, R.; Xie, R.; Meng, Z.; Ma, S.; Guan, K.L. STRIPAK integrates upstream signals to initiate the Hippo kinase cascade. Nat. Cell Biol. 2019, 21, 1565-1577. [CrossRef]

11. Jeong, B.C.; Bae, S.J.; Ni, L.; Zhang, X.; Bai, X.C.; Luo, X. Cryo-EM structure of the Hippo signaling integrator human STRIPAK. Nat. Struct. Mol. Biol. 2021, 28, 290-299. [CrossRef]

12. Huang, W.; Leonard, D.; Taylor, D.J. Pack a STRIPAK with hubs inside a hub. Nat. Struct. Mol. Biol. 2021, 28, 232-233. [CrossRef] [PubMed]

13. Kück, U.; Pöggeler, S.; Nowrousian, M.; Nolting, N.; Engh, I. Sordaria macrospora, a model system for fungal development. In The Mycota XV; Anke, T., Weber, D., Eds.; Springer: Heidelberg, Germany, 2009; pp. 17-39.

14. Xiang, Q.; Rasmussen, C.; Glass, N.L. The ham-2 locus, encoding a putative transmembrane protein, is required for hyphal fusion in Neurospora crassa. Genetics 2002, 160, 169-180. [CrossRef] [PubMed]

15. Dettmann, A.; Heilig, Y.; Ludwig, S.; Schmitt, K.; Illgen, J.; Fleissner, A.; Valerius, O.; Seiler, S. HAM-2 and HAM-3 are central for the assembly of the Neurospora STRIPAK complex at the nuclear envelope and regulate nuclear accumulation of the MAP kinase MAK-1 in a MAK-2-dependent manner. Mol. Microbiol. 2013, 90, 796-812. [CrossRef] [PubMed]

16. Fu, C.; Ao, J.; Dettmann, A.; Seiler, S.; Free, S.J. Characterization of the Neurospora crassa cell fusion proteins, HAM-6, HAM-7, HAM-8, HAM-9, HAM-10, AMPH-1 and WHI-2. PLOS ONE 2014, 9, e107773. [CrossRef] [PubMed]

17. Simonin, A.R.; Rasmussen, C.G.; Yang, M.; Glass, N.L. Genes encoding a striatin-like protein (ham-3) and a forkhead associated protein (ham-4) are required for hyphal fusion in Neurospora crassa. Fungal Genet. Biol. 2010, 47, 855-868. [CrossRef]

18. Bloemendal, S.; Lord, K.M.; Rech, C.; Hoff, B.; Engh, I.; Read, N.D.; Kück, U. A mutant defective in sexual development produces aseptate ascogonia. Eukaryot. Cell 2010, 9, 1856-1866. [CrossRef]

19. Radchenko, D.; Teichert, I.; Pöggeler, S.; Kück, U. A Hippo pathway-related GCK controls both sexual and vegetative developmental processes in the fungus Sordaria macrospora. Genetics 2018, 210, 137-153. [CrossRef]

20. Beier, A.; Teichert, I.; Krisp, C.; Wolters, D.A.; Kück, U. Catalytic subunit 1 of protein phosphatase 2A is a subunit of the STRIPAK complex and governs fungal sexual development. mBio 2016, 7, e00870-16. [CrossRef]

21. Bayram, O.; Braus, G.H. Coordination of secondary metabolism and development in fungi: The velvet family of regulatory proteins. FEMS Microbiol. Rev. 2012, 36, 1-24. [CrossRef]

22. Green, K.A.; Becker, Y.; Fitzsimons, H.L.; Scott, B. An Epichloë festucae homologue of MOB3, a component of the STRIPAK complex, is required for the establishment of a mutualistic symbiotic interaction with Lolium perenne. Mol. Plant. Pathol. 2016, 17, 1480-1492. [CrossRef]

23. Shim, W.B.; Sagaram, U.S.; Choi, Y.E.; So, J.; Wilkinson, H.H.; Lee, Y.W. FSR1 is essential for virulence and female fertility in Fusarium verticillioides and F. graminearum. Mol. Plant. Microbe Interact. 2006, 19, 725-733. [CrossRef]

24. Yamamura, Y.; Shim, W.B. The coiled-coil protein-binding motif in Fusarium verticillioides Fsr1 is essential for maize stalk rot virulence. Microbiology 2008, 154, 1637-1645. [CrossRef]

25. Zhang, H.; Mukherjee, M.; Kim, J.E.; Yu, W.; Shim, W.B. Fsr1, a striatin homologue, forms an endomembrane-associated complex that regulates virulence in the maize pathogen Fusarium verticillioides. Mol. Plant. Pathol. 2018, 19, 812-826. [CrossRef]

26. Wang, C.L.; Shim, W.B.; Shaw, B.D. The Colletotrichum graminicola striatin orthologue Str1 is necessary for anastomosis and is a virulence factor. Mol. Plant. Pathol. 2016, 17, 931-942. [CrossRef]

27. Islam, K.T.; Bond, J.P.; Fakhoury, A.M. FvSTR1, a striatin orthologue in Fusarium virguliforme, is required for asexual development and virulence. Appl. Microbiol. Biotechnol. 2017, 101, 6431-6445. [CrossRef] [PubMed] 
28. Du, Y.; Shi, Y.; Yang, J.; Chen, X.; Xue, M.; Zhou, W.; Peng, Y.L. A serine/threonine-protein phosphatase PP2A catalytic subunit is essential for asexual development and plant infection in Magnaporthe oryzae. Curr. Genet. 2013, 59, 33-41. [CrossRef]

29. Youssar, L.; Wernet, V.; Hensel, N.; Yu, X.; Hildebrand, H.G.; Schreckenberger, B.; Kriegler, M.; Hetzer, B.; Frankino, P.; Dillin, A.; et al. Intercellular communication is required for trap formation in the nematode-trapping fungus Duddingtonia flagrans. PLoS Genet. 2019, 15, e1008029. [CrossRef] [PubMed]

30. Chen, S.A.; Lin, H.C.; Schroeder, F.C.; Hsueh, Y.P. Prey sensing and response in a nematode-trapping fungus is governed by the MAPK pheromone response pathway. Genetics 2021, 217. [CrossRef] [PubMed]

31. Vidal-Diez de Ulzurrun, G.; Hsueh, Y.P. Predator-prey interactions of nematode-trapping fungi and nematodes: Both sides of the coin. Appl. Microbiol. Biotechnol. 2018, 102, 3939-3949. [CrossRef]

32. Fisher, M.C.; Gurr, S.J.; Cuomo, C.A.; Blehert, D.S.; Jin, H.; Stukenbrock, E.H.; Stajich, J.E.; Kahmann, R.; Boone, C.; Denning, D.W.; et al. Threats posed by the fungal kingdom to humans, wildlife, and agriculture. mBio 2020, 11. [CrossRef]

33. Pracheil, T.; Liu, Z. Tiered assembly of the yeast Far3-7-8-9-10-11 complex at the endoplasmic reticulum. J. Biol. Chem. 2013, 288, 16986-16997. [CrossRef]

34. Ast, J.; Stiebler, A.C.; Freitag, J.; Bölker, M. Dual targeting of peroxisomal proteins. Front. Physiol. 2013, 4, 297. [CrossRef]

35. Dunn, C.D.; Paavilainen, V.O. Wherever I may roam: Organellar protein targeting and evolvability. Curr. Opin. Genet. Dev. 2019, 58, 9-16. [CrossRef]

36. Nordzieke, S.; Zobel, T.; Franzel, B.; Wolters, D.A.; Kück, U.; Teichert, I. A fungal sarcolemmal membrane-associated protein (SLMAP) homolog plays a fundamental role in development and localizes to the nuclear envelope, endoplasmic reticulum, and mitochondria. Eukaryot. Cell 2015, 14, 345-358. [CrossRef] [PubMed]

37. Frost, A.; Elgort, M.G.; Brandman, O.; Ives, C.; Collins, S.R.; Miller-Vedam, L.; Weibezahn, J.; Hein, M.Y.; Poser, I.; Mann, M.; et al. Functional repurposing revealed by comparing S. pombe and S. cerevisiae genetic interactions. Cell 2012, 149, 1339-1352. [CrossRef] [PubMed]

38. Byers, J.T.; Guzzo, R.M.; Salih, M.; Tuana, B.S. Hydrophobic profiles of the tail anchors in SLMAP dictate subcellular targeting. BMC Cell Biol. 2009, 10, 48. [CrossRef] [PubMed]

39. Guzzo, R.M.; Salih, M.; Moore, E.D.; Tuana, B.S. Molecular properties of cardiac tail-anchored membrane protein SLMAP are consistent with structural role in arrangement of excitation-contraction coupling apparatus. Am. J. Physiol. Heart Circ. Physiol. 2005, 288, H1810-H1819. [CrossRef]

40. Guzzo, R.M.; Sevinc, S.; Salih, M.; Tuana, B.S. A novel isoform of sarcolemmal membrane-associated protein (SLMAP) is a component of the microtubule organizing centre. J. Cell Sci. 2004, 117, 2271-2281. [CrossRef]

41. Wigle, J.T.; Demchyshyn, L.; Pratt, M.A.; Staines, W.A.; Salih, M.; Tuana, B.S. Molecular cloning, expression, and chromosomal assignment of sarcolemmal-associated proteins. A family of acidic amphipathic alpha-helical proteins associated with the membrane. J. Biol. Chem. 1997, 272, 32384-32394. [CrossRef]

42. Csordás, G.; Renken, C.; Várnai, P.; Walter, L.; Weaver, D.; Buttle, K.F.; Balla, T.; Mannella, C.A.; Hajnóczky, G. Structural and functional features and significance of the physical linkage between ER and mitochondria. J. Cell Biol. 2006, 174, 915-921. [CrossRef]

43. Märker, R.; Blank-Landeshammer, B.; Beier-Rosberger, A.; Sickmann, A.; Kück, U. Phosphoproteomic analysis of STRIPAK mutants identifies a conserved serine phosphorylation site in PAK kinase CLA4 to be important in fungal sexual development and polarized growth. Mol. Microbiol. 2020, 113, 1053-1069. [CrossRef]

44. Stein, V.; Blank-Landeshammer, B.; Müntjes, K.; Märker, R.; Teichert, I.; Feldbrügge, M.; Sickmann, A.; Kück, U. The STRIPAK signaling complex regulates dephosphorylation of GUL1, an RNA-binding protein that shuttles on endosomes. PLoS Genet. 2020, 16, e1008819. [CrossRef] [PubMed]

45. Innokentev, A.; Furukawa, K.; Fukuda, T.; Saigusa, T.; Inoue, K.; Yamashita, S.I.; Kanki, T. Association and dissociation between the mitochondrial Far complex and Atg32 regulate mitophagy. Elife 2020, 9. [CrossRef] [PubMed]

46. Furukawa, K.; Innokentev, A.; Kanki, T. Mitophagy regulation mediated by the Far complex in yeast. Autophagy 2021, 1-2. [CrossRef]

47. Werner, A.; Herzog, B.; Frey, S.; Pöggeler, S. Autophagy-associated protein SmATG12 is required for fruiting-body formation in the filamentous ascomycete Sordaria macrospora. PLoS ONE 2016, 11, e0157960. [CrossRef] [PubMed]

48. Voigt, O.; Pöggeler, S. Self-eating to grow and kill: Autophagy in filamentous ascomycetes. Appl. Microbiol. Biotechnol. 2013, 97, 9277-9290. [CrossRef]

49. Pickles, S.; Vigie, P.; Youle, R.J. Mitophagy and quality control mechanisms in mitochondrial maintenance. Curr. Biol. 2018, 28, R170-R185. [CrossRef] [PubMed]

50. Kirkin, V.; Rogov, V.V. A diversity of selective autophagy receptors determines the specificity of the autophagy pathway. Mol. Cell 2019, 76, 268-285. [CrossRef] [PubMed]

51. Murakawa, T.; Yamaguchi, O.; Hashimoto, A.; Hikoso, S.; Takeda, T.; Oka, T.; Yasui, H.; Ueda, H.; Akazawa, Y.; Nakayama, H.; et al. Bcl-2-like protein 13 is a mammalian Atg32 homologue that mediates mitophagy and mitochondrial fragmentation. Nat. Commun. 2015, 6, 7527. [CrossRef]

52. Nowrousian, M.; Stajich, J.E.; Chu, M.; Engh, I.; Espagne, E.; Halliday, K.; Kamerewerd, J.; Kempken, F.; Knab, B.; Kuo, H.C.; et al De novo assembly of a $40 \mathrm{Mb}$ eukaryotic genome from short sequence reads: Sordaria macrospora, a model organism for fungal morphogenesis. PLoS Genet. 2010, 6, e1000891. [CrossRef] [PubMed] 
53. Blank-Landeshammer, B.; Teichert, I.; Märker, R.; Nowrousian, M.; Kück, U.; Sickmann, A. Combination of proteogenomics with peptide de novo sequencing identifies new genes and hidden posttranscriptional modifications. mBio 2019, 10. [CrossRef] [PubMed]

54. Kou, Y.; He, Y.; Qiu, J.; Shu, Y.; Yang, F.; Deng, Y.; Naqvi, N.I. Mitochondrial dynamics and mitophagy are necessary for proper invasive growth in rice blast. Mol. Plant. Pathol. 2019, 20, 1147-1162. [CrossRef] [PubMed]

55. Teichert, I.; Pöggeler, S.; Nowrousian, M. Sordaria macrospora: 25 years as a model organism for studying the molecular mechanisms of fruiting body development. Appl. Microbiol. Biotechnol. 2020, 104, 3691-3704. [CrossRef]

56. Wang, J.J.; Peng, Y.J.; Ding, J.L.; Feng, M.G.; Ying, S.H. Mitochondrial fission is necessary for mitophagy, development and virulence of the insect pathogenic fungus Beauveria bassiana. J. Appl. Microbiol. 2020, 129, 411-421. [CrossRef]

57. Warnsmann, V.; Marschall, L.M.; Osiewacz, H.D. Impaired F1Fo-ATP-Synthase dimerization leads to the induction of cyclophilin D-mediated autophagy-dependent cell death and accelerated aging. Cells 2021, 10, 757. [CrossRef]

58. Stein, V.; Blank-Landeshammer, B.; Märker, R.; Sickmann, A.; Kück, U. Targeted Quantification of Phosphorylation Sites Identifies STRIPAK-Dependent Phosphorylation of the Hippo Pathway-Related Kinase SmKIN3. mBio 2021. [CrossRef]

59. Schmidpeter, J.; Dahl, M.; Hofmann, J.; Koch, C. ChMob2 binds to ChCbk1 and promotes virulence and conidiation of the fungal pathogen Colletotrichum higginsianum. BMC Microbiol. 2017, 17, 22. [CrossRef]

60. März, S.; Dettmann, A.; Ziv, C.; Liu, Y.; Valerius, O.; Yarden, O.; Seiler, S. Two NDR kinase-MOB complexes function as distinct modules during septum formation and tip extension in Neurospora crassa. Mol. Microbiol. 2009, 74, 707-723. [CrossRef]

61. Fu, C.; Iyer, P.; Herkal, A.; Abdullah, J.; Stout, A.; Free, S.J. Identification and characterization of genes required for cell-to-cell fusion in Neurospora crassa. Eukaryot. Cell 2011, 10, 1100-1109. [CrossRef]

62. Bernhards, Y.; Pöggeler, S. The phocein homologue SmMOB3 is essential for vegetative cell fusion and sexual development in the filamentous ascomycete Sordaria macrospora. Curr. Genet. 2011, 57, 133-149. [CrossRef]

63. Choi, Y.E.; Shim, W.B. Functional characterization of Fusarium verticillioides CPP1, a gene encoding a putative protein phosphatase 2A catalytic subunit. Microbiology 2008, 154, 326-336. [CrossRef]

64. Rodriguez-Iglesias, A.; Schmoll, M. Protein phosphatases regulate growth, development, cellulases and secondary metabolism in Trichoderma reesei. Sci. Rep. 2019, 9, 10995. [CrossRef]

65. Reschka, E.J.; Nordzieke, S.; Valerius, O.; Braus, G.H.; Pöggeler, S. A novel STRIPAK complex component mediates hyphal fusion and fruiting-body development in filamentous fungi. Mol. Microbiol. 2018, 110, 513-532. [CrossRef]

66. Gautier, V.; Tong, L.C.H.; Nguyen, T.S.; Debuchy, R.; Silar, P. PaPro1 and IDC4, two genes controlling stationary phase, sexual development and cell degeneration in Podospora anserina. J. Fungi 2018, 4, 85. [CrossRef] [PubMed]

67. Bloemendal, S.; Bernhards, Y.; Bartho, K.; Dettmann, A.; Voigt, O.; Teichert, I.; Seiler, S.; Wolters, D.A.; Pöggeler, S.; Kück, U. A homologue of the human STRIPAK complex controls sexual development in fungi. Mol. Microbiol. 2012, 84, 310-323. [CrossRef]

68. Wang, C.; Zhang, S.; Hou, R.; Zhao, Z.; Zheng, Q.; Xu, Q.; Zheng, D.; Wang, G.; Liu, H.; Gao, X.; et al. Functional analysis of the kinome of the wheat scab fungus Fusarium graminearum. PLoS Pathog. 2011, 7, e1002460. [CrossRef] [PubMed]

69. De Souza, C.P.; Hashmi, S.B.; Osmani, A.H.; Andrews, P.; Ringelberg, C.S.; Dunlap, J.C.; Osmani, S.A. Functional analysis of the Aspergillus nidulans kinome. PLoS ONE 2013, 8, e58008. [CrossRef] [PubMed]

70. Heilig, Y.; Schmitt, K.; Seiler, S. Phospho-regulation of the Neurospora crassa septation initiation network. PLoS ONE 2013, 8, e79464. [CrossRef]

71. Frey, S.; Reschka, E.J.; Pöggeler, S. Germinal center kinases SmKIN3 and SmKIN24 are associated with the Sordaria macrospora striatin-interacting phosphatase and kinase (STRIPAK) complex. PLoS ONE 2015, 10, e0139163. [CrossRef]

72. Frey, S.; Lahmann, Y.; Hartmann, T.; Seiler, S.; Pöggeler, S. Deletion of Smgpi1 encoding a GPI-anchored protein suppresses sterility of the STRIPAK mutant $\Delta$ Smmob3 in the filamentous ascomycete Sordaria macrospora. Mol. Microbiol. 2015, 97, 676-697. [CrossRef] [PubMed]

73. Wang, C.L.; Shim, W.B.; Shaw, B.D. Aspergillus nidulans striatin (StrA) mediates sexual development and localizes to the endoplasmic reticulum. Fungal Genet. Biol. 2010, 47, 789-799. [CrossRef] [PubMed] 